\title{
Preserving the dead
}

\section{Haunting auras}

From the earliest antiquarian letters to the poetic evocations of Heaney, the words used to describe bog bodies conjure their remarkable yet unsettling power. They are 'entire and uncorrupted' (Leigh 1700: 65), found as 'in a common posture of sleep' (de la Pryme 1870: 983), 'as fresh as if death had occurred the preceding day' (Gear 1883, cited in Cowie et al. 2011: 8). Yet the bog has inevitably altered and stained these remains; they are described by Low as 'rolled up in their own leather' (cited in Anderson 1879: liii) or 'tanned and dried in a remarkable manner' (Lukis 1892: ix). The slightly glossy, madder-brown hue produced by the peat thus lends such remains a sense of antiquity, even permanence. Heaney (1972: 36) captures this beautifully in 'The Tollund Man': the fen's 'dark juices working / Him to a saint's kept body'. Glyn Daniel also evoked how this corpse produced a sense of 'humanity, serenity ... as if carved in ebony' while his fellow presenter, Mortimer Wheeler, described him as 'the most haunting relic of antiquity I have ever seen' (BBC 1954).

Such 'haunting power' arises from the eerie lifelikeness of a bog body. Even recently, Irish curator Rolly Reed revealed that he felt 'freaked' by the enormous reach of Old Croghan Man's arms and his perfect fingerprints, admitting to flashbacks and nightmares (cited in Grice 2006: 19-21). He could have been, as Reed put it, anyone from the streets of Dublin. The bog appears to have stopped decay, or at least to have stilled it. The things caught in its waters appear to stand outside of time - although we know they are dead these ancient bodies somehow defy mortality. For some, this near-living afterlife creates a sense of immortality, of hope even, in the face of our own finitude. Yet their unique material valence, their 'fleshiness and overt corporeality', is unsettling - mirroring life while being clearly estranged from it (Sanders 2009: 50). For others, it creates unease, since 'what should be dead appears to be alive' (Wallace 2004: 57). Meeting such remains can produce 'feelings of confusion, alarm, surprise, even trickery, prompting us to reconcile what can seem to be contradictory facts and categorical boundaries' (Fredengren 2016: 492). Bog bodies thus epitomise Freud's concept 
of 'the uncanny', a quality related principally to 'death, dead bodies, revenants, spirits and ghosts' (Sanders 2009: 49): 'everything is uncanny [unheimlich - literally 'unhomely'] that ought to have remained secret and hidden but has come to light' (Freud [1919] 2003: 126). Accordingly, Moshenska (2006: 93) argues that it is strictly the process of exhuming remains from the peat - the transgressive act of bringing the hidden to light - which renders them uncanny, not any innate material property. Yet Sanders (2009: 49) also grounds their troubling power in the fear that that an apparently lifeless find could once more be made animate, reading into these remains a provocative, revenant agency.

This power of bog bodies was realised in an incident in Freud's own life. He was an ardent collector of classical antiquities, being fascinated in particular by Pompeii and the plaster casts of bodies, revealed by infilling the bodily voids immortalised in consolidated tephra and ash (Sanders 2009, fig. 2.1). These 'traces' of bodies became, through Fiorelli's reproductions, analogous to the marbled skin of classical sculptures. Freud also used the metaphor of stratigraphic excavation to drive his psychological method, believing that analysis could 'uncover' the deep and repressed layers of a patient's psyche in an ordered, rational manner. Yet he found himself psychologically overwhelmed by his protégé Jung's description of the black morass of the bog from which spilled such distorted, warped remains (Sanders 2009: 50-1). Freud fainted, repulsed by this spewing mire and its regurgitation of the primitive and uncivilised: a 'black tide of mud', as Freud himself put it, without ordered depths. He was, Jung recalled, 'vexed ... [by] all this chatter about corpses', convinced this was part of Jung's subliminal, fratricidal thoughts towards his past mentor (cited in Sanders 2009: 51).

Why was Freud repulsed and haunted by such archaeology? By their nature, bog bodies do not simply endure through time, like a ruin. They do not gradually erode in profile, fragmenting, gathering lichens, cracks and repairs that become the material manifestation of what the late nineteenth-century art historian Riegl ([1903] 1982: 31-2) called an object's 'age-value': a concept developed for architecture and artefacts not human remains (DeSilvey 2017). Yet the bog body can be considered an excellent example of Riegl's (1903] 1982: 24) 'catalysts', which 'trigger in the beholder a sense of the life cycle, of the emergence of the particular from the general and its gradual but inevitable dissolution ... evoked by mere sensory perception'. Nonetheless, their very failure to rot and decay immediately causes a problem. The leather-like appearance noted by many archaeologists and poets might give them a weather-beaten, wrung and worn-out finish but there is no 'steady decay', no sign of the gradual 'wear and tear' that Riegl (1903] 1982: 312) sought, where footfall or handhold has rubbed a recognizable patina. They disrupt our expectations of the ancient. This gives them a very different 'aura' to other archaeological fragments.

What do we mean by the term 'aura'? In 1936, Walter Benjamin (1969: 221) defined an artwork's 'aura' as the 'unique existence' of a thing in time and space, its 'substantive duration' as well as 'the history it has experienced'. Aura is perceived as a sensory closeness to that which is distant in time (Riegl [1903] 1982: 24). 
However, unlike the monuments we live alongside (from which, as Musil puts it, our attention drips like water from an oilskin, cited in Taussig 1999: 91), the aura of a bog body derives in part from its sudden and rupturing emergence. The peat cutter's spade collapses time in its incisive 'cut', throwing the past up and out into the present. They are the living embodiment of the way in which Olivier (2015) and Lucas (2004) encourage us to conceptualise time not as a simple successive and linear sequence from past to present but as points of contact between materialities of different time depths. As Fredengren (2016: 489) summarises, 'the deep time of archaeology ... is better described as scrunched or folded, "touching" in unexpected, particular or specific points'. Bog bodies then, are not merely uncanny but unnerving in their subversion of the order we expect in time and the effect we expect time to take: summoning us, demanding attention as they burst into our present.

Few of these corpses, as Sanders (2009: 56) notes, can lay claim to 'physiognomic beauty'- they are distorted, flattened, warped. Pye (2001a: 175) likewise questions whether it is appropriate to display human remains retaining soft tissue, 'since their power to horrify is greater than human bones alone'. Yet this obdurate 'thereness ... their stubborn materiality' (Sanders 2009: xiv-xv), is both morbid and touching. Individualised humanity is still recognisable: trimmed nails, beautiful plaits of hair and skeins of cloth with their coloured weave. As a result, archaeologists often refer to them as 'bodies' not 'corpses', even retaining a personal pronoun where known ('he', 'she' not 'it') (Sanders 2009: 7). The power of encounters with well-preserved 'deep-time' objects can thus also be 'enchanting' (Fredengren 2016: 492). Indeed, Fredengren (2016) argues vociferously that the eruptive emergences of bog bodies can be part of how we become more viscerally connected to the temporality of human occupation in a place, and our intergenerational obligations to these environments - now, apparently, so central to our future survival (see Chapter 1). She draws here on Bennett's definition of being enchanted as 'being struck or shaken', and 'a state of open-ness to the disturbing-captivating elements of everyday experience' in such a way that it generates ethical potential (Bennett 2010: 131). Well-preserved human remains, Fredengren muses, can thus be particularly powerful kinds of cultural ghosts, for as often as they inspire awe, they shock us with evidence for violence: the 'dark elderberry place', as Heaney puts it, of Grauballe Man's gashed throat ('The Grauballe Man', 1975), the 'soiled bandage' of Yde Girl's 'blindfold' ('Punishment', 1975). Beyond the stilted fear, the hesitancy to approach, comes the urge to tend to these lives, described evocatively by conservator Valerie Hall when dealing with the same remains that so haunted her colleague: 'Nothing was said, but I noticed how we all reached out and held Old Croghan Man's hand. It was a reassurance across the aeons that we intended no harm. The harm done to those men in their lives was heart-wrenching' (cited in Grice 2006: 20). As Sanders (2009: 223) simply puts it: 'their having-been speaks to our being. This ambiguous aura is created through preservation: both 'natural' (in the bog) and cultural (though the acts of conservators in museums). The next section begins with the musings of the antiquarians and early scientists before 
reviewing contemporary theories on peat preservation. As we shall see, there is still much to discover.

\section{'Kept bodies': the preservative power of the bog}

Many of the antiquarian writers described the bog's effect in terms of its analogy with hide and leatherwork. Low considered the Summersdale body to be 'preserved by a natural tanning ... by the action of the moss water ... as if in a tan pit' (cited in Anderson 1879: liii). Writing about remains from Austwick Common near Leeds, Denny also refers to 'the tanning property of the peat', but he also cites John Lubbock's report on the coffin burials at Tremhoi, to wonder if such preservation was the result of bog 'water ... strongly impregnated with iron' (Denny 1871: 177). He goes on to note that in the case of the Austwick bog skeleton 'the bones are excessively light ... they have lost all their earthy material, probably owing to the action of some acid' (Denny 1871: 162, 168). Here we have an early, detailed report on cases where 'nearly all the animal substance disappears ... as relates to the human body ... while the woolen clothing and the wooden coffins remains in a completely perfect condition' (Denny 1871: 176). Another skeletonised body was found at Lochar Moss I, where the bones and clothing were preserved but the flesh had decomposed apart from a single toenail (Cowie et al. 2011: 37). In contrast, Abraham de la Pryme (1701: 983) notes the power of 'Moor water' to preserve the flesh but consume the bone. Hunt's (1866a, 1866b) work on Shetland was motivated by this suspicion that it was not purely the peat nor the bog water that led to the preservation of skin and tissue, noting the differential preservation both within and between corpses even within the small area of the Bressay 'cemetery'.

The power of the Peak District's peaty soils were well known to its inhabitants. As Balguy (1735: 415) reported to the Royal Society, 'There are no Means known (I believe) of preserving Bodies so well'. Charles Cox (1877: 265) also mentions the 'antiseptic qualities of the soil', which he comments led to 'various extraordinary instances ... in preserving dead bodies', including one unfortunate interment in Hathersage churchyard. Mr Benjamin Ashton was exhumed by a relative fifty-six years after his burial in 1781, whence 'the body was found congealed and hard as flint' and was seen by one Jenny Sherd 'reared upright in the church'; however, the corpse fell in the nave, and its head became detached (Cox 1877: 236). Her father tried to saw a piece out of the corpse 'as a relic' but the blade 'would not make the slightest impression' (Cox 1877: 236). Cox (1877: 265) goes on to cite in full the letter of the minister, Wormald, who attended the final exhumation of the Hope couple. In old age, Wormald recalls that while the peat was moist, it was not waterlogged (Balguy 1735: 413, 415) . Yet in Balguy's (1735: 414) account of this repeatedly disturbed burial we can see a finer observation that the repeated exhumation and manhandling of the woman's body led to her disproportionate decay, compared with the grazier himself. By the mid to late nineteenth century there was an 
awareness that while peaty bog water was involved in the process of preservation, the results of immersion were not constant or predictable.

Such observations led these authors to make comparisons with other wellpreserved remains - the Grewelthorpe Moor bog body was described as 'tanned and dried in a remarkable manner, somewhat like an Egyptian mummy' (Lukis 1892: ix). Leigh (1700: 64) (who noted almost in passing the discovery of bodies 'entire and uncorrupted' from the bogs of Cheshire and Lancashire) notes the peculiar power of a 'bituminous Turf' from Hasil (near Ormskirk) that was highly flammable but also acted as a preservative: 'I have seen strange Effects of it in preserving Raw Flesh, which comes near to the Aegyptian Mummy'. Balguy (1735) also cites Egyptian remains and contemporary British embalming techniques. These early experimenters mixed mineral, culinary, herbal and medicinal substances (including the power of natron or the antiseptic property of honey) to delay decomposition. Embalming was certainly used in the case of Oliver Cromwell, whose rapidly decaying body threatened to undermine his post-mortem reputation (corporeal decay being an index of sanctity, see Tarlow 2008: 70). Ironically it was this very act of preservation that later allowed Cromwell's corpse to be disinterred during the restoration of the monarchy, where it was tried, hanged by the neck and 'decapitated' to become a humiliating display on a spike above Westminster Hall (Tarlow 2008: 74-5). Searching for other analogies, the antiquarian Denny (1871: 173) not only cites 'the frozen and entire bodies of mammoth and rhinoceros in Siberia, but the instance of the mineralisation of a worker trapped deep in a mine, as well as a young pilgrim/trader in the Alps, found frozen in a glacial crevice: 'embalmed in ice, decay had not yet touched his flesh'. Medical and chemical intervention, extreme heat, extreme cold and extreme wetness, as well as the airless aridity of the vault - the classic explanations of corporeal preservation had already been fathomed by these authors (see Chamberlain and Parker Pearson 2001; Giles 2013). Yet living in an era of pre-refrigeration, they also have lessons for us to learn. In his account of Scottish 'mummies', Low mourns the reburial of some remains but informs his readers of how these particular corpses seem to have been curated:

In Walls, likewise, there were well preserved mummies but they were buried by a superstitious old woman. These were preserved in the same manner as you have no doubt heard of mutton or beef by skewing, that is by placing the body in a situation where the air can get in to absorb the juices, but insects are excluded; so that in time, the body becomes like a dried haddock. (Cited in Anderson 1879: liii-liv)

His knowledge of localised wind-drying techniques is instructive, as Chamberlain and Parker Pearson (2001) make a cogent argument that the mortuary skills needed to 'cure' or preserve a corpse would have been drawn from analogous domains of knowledge: cooking (salting, preserving, maturing and curing, wind-drying, desiccating, cooling, smoking), textile and hide work (retting, stitching, stuffing and packing) and of course, primitive medical interventions (wound dressing and binding, excision and amputation) (see also Giles 2013: 489-90; Tollefsen 2016). 
One of the key research questions that Chapter 6 will probe is whether later prehistoric communities knew of the preservative properties of the bog itself and knowingly exploited it, to different ends.

Another factor repeatedly cited by these authors to explain the phenomenon of preservation was the medicinal, 'antiseptic' power of bog water, referred to by Pitiscus of Oldenberg (1791, cited in van der Sanden 1996: 19) as 'the real quintessence. In a prescient passage that anticipates modern modes of passive conservation, he suggests that bog bodies could be stored in peat water so that future generations might see what they looked like. Simpson (1846, cited in Cowie et al. 2011: 16) also comments on 'the antiseptic quality of the moss', while Low (cited in Anderson 1879: 140) considered 'the styptic quality of the waters of our mosses' to be an additional factor in the tanning process. Charles Lyell (1838: 723) mused that the 'antiseptic properties of the peat' arose from the charcoal or resinouslike decay of the trees found in its basal layers. However, he also cites the ideas of one Dr MacCulloch that the marvellous properties of bog water were somehow influenced by its plant species- an idea ahead of its time (Lyell 1838: 723). While Pitiscus suggested experiments to test his ideas (burying animals in bogs both with skins and flayed, to evaluate their 'tanning' every fortnight), van der Sanden (1996: 19) identifies three antiquarian experimenters who actually tested the properties of peat to preserve - von Pfeiffer, Thorey and Gieske. Gieske immersed small sections of skin in water infused by peat dust, removing it after ten days to dry, and reported that it resembled the worn sole of a shoe (van der Sanden 1996: 19). Finally, in an experiment that would be unlikely to receive ethical approval today, the Danish pathologist Ellermann buried 'human skin and bones' in a peat bog, at the turn of the twentieth century, for a period of two years and four months (van der Sanden 1996: 19). He noted that even after this relatively short period, the skin had turned dark brown while the bones were partially decalcified. Ellermann went to conduct further comparative experiments and worked on the bog body known as Vester Torstad (Lynnerup 2015). He concluded that the 'Sphagnum acid' was key to this process and argued that only raised bogs would produce this 'tanning' effect (Ellermann 1916).

Modern scientific analysis of the bog environment has honed our understanding of what is actually behind this marvellous effect of preservation. We know that the rapid growth of peat and the manner in which it compacts results in an anaerobic (oxygen-excluding) environment (Stead et al. 1986). This helps reduce organic decomposition both of local plant matter and anything organic strayed cattle, lost wooden tools or bog bodies - entering its domain (van der Sanden 1996). The dominant model that explains what happens next is known as the 'sphagnan theory' (Painter 1991). Sphagnum exchanges hydrogen ions for metal ions, gradually producing small quantities of sulphuric acid that mix with the humic acid formed by bacterial decay of lignin in the peat (Granite 2014). This results in a common pH value of 3.2-4.5 (Asingh 2009), and a nutrient poor habitat, fed only by rainwater. Surrounding tree roots, reeds and other plant life cannot tolerate this acid environment, dying to create a plant-rich basal layer to the 
bog (to which we will return in Chapter 4). As the bog grows and expands, these acids further inhibit the growth of bacteria in both plant matter and bog water. As indicated above, this antibacterial effect has been known for centuries: the powerful phenol compounds in Sphagnum moss were invaluable in the days before penicillin, drawing on centuries of folkloric knowledge in Scotland, Ireland and Germany among others (Asingh 2009: 135). Dried Sphagnum moss was used in field dressings during the First World War due both to its antibacterial (or in antiquarian terms, antiseptic) qualities (Boissoneault 2017). The same ability to absorb rainwater into the largely 'empty' cells of Sphagnum tissue made it an excellent absorbent for bodily fluids and infectious matter (Watson 2014).

Painter (1995: 98-9) argues it is the sphagnan itself (a natural sugar that he identified) - released from the moss - that neutralises any nutrient-rich nitrogen, binding with the digestive enzymes of putrefactive bacteria to starve and immobilise them, preventing further decay. Meanwhile, fen carr, benefitting from greater mineral input, can sometimes produce an alkaline environment, explaining those examples of bog bodies where the skeleton is preserved but tissue is eaten away (Gill-Robinson 2007). The above biochemistry explains the cessation of decomposition and the differential preservation of tissue and bone, but it does not explain the characteristic 'tanned' appearance of a bog body. Painter (1998) argues this is due to a further 'Maillard' reaction in which sugars and amino acids form dark-brown polymers, giving the bog body its final leathered appearance and characteristic red hair (Painter 1995: 134-5; Painter 2003). It is important to note that the 'sphagnan model' has been queried by Ballance et al. (2008), who propose instead that electrostatic interactions between amino groups and sugars are responsible for such 'tanning' and preservation (see also Nguyen and Harvey 2001; Hsu and Hatcher 2006; Lynnerup 2015: 1008). Research by Stankiewicz et al. (1997) and Freeman et al. (2004), meanwhile, suggests Painter's model still has merit. Their results particularly support the importance of phenolic compounds in the acid bog water as crucial to the preservative effects noticed in bog bodies.

What is not disputed is that the acidic environment tends to decalcify bone (Asingh 2009: 134). Bone mineral is leached from the skeleton while simultaneously mineral salts (often rich in iron) are readily absorbed into the collagenous soft tissues (Lynnerup 2007). Unfortunately, this complicates any attempts to identify applications such as pigments on human skin or certain kinds of tanning agents and dyes on hide products (Lynnerup 2007; see also Chapter 5). The soft tissues are transformed into a leather-like substance, affecting skin, cartilage and sinew. Waterlogging will saturate a well-immersed body but this can lead both to the loss of the outer epidermis of the skin, which Lynnerup (2015: 1008) compares with the forensic phenomenon of 'washer-women's hands' and dramatic warping and notable shrinkage, if such wet remains are allowed to dry out naturally.

As Granite (2014: 15) notes, the exact preservative power of the peat bog is still 'a challenging area of research', which continues to slightly mystify us, as it did antiquarian scholars. What we can certainly take from all these studies is the 
realisation that additional factors determine whether a body will be well preserved or not. Some of these are anthropogenic, relating to the condition of the individual near death and the treatment of the body soon after, such as whether a head was decapitated or whether remains retained bodily integrity or were kept, displayed or curated for a while (see Nieuwhof 2015; Fredengren 2018; see also Chapter 6). Assuming a whole body was deposited in the bog, however, we know that immersion in cold weather (with a water temperature below $4^{\circ} \mathrm{C}$ ) seems key (Fischer 2012: 67), preferably in a damp/wet pit, open pool or bog lake (Lynnerup 2015), which would lead to swift submersion in limnic muds (Buckland 1995). Thus, the season of death, weather conditions and rapid encapsulation of the body are also important (Ravn 2010, fig. 2). While it is unlikely that a corpse would resurface from such a pool, since putrefaction and thus the formation of post-mortem gasses were suppressed, the additional weighting or 'staking down' of several bog bodies (such as the Windeby Youth, see Aldhouse-Green 2016: front cover) would reinforce deep immersion. Given the fear of the revenant discussed above, it might suggest this was as much a thanatological strategy as a practical concern (van der Sanden 1996: 98-9; Aldhouse-Green 2004a). Having discussed different understandings of the biochemistry of the bog, we now turn to the strategies by which archaeologists have tried to finish the process the bogs had begun.

\section{The archaeological conservation of bog bodies}

The moss and mire may have 'sabotaged and subverted' the hand of time (Sanders 2009: 60), but the moment a body emerges from the bog, time's handiwork starts again. This not only alters the aesthetic appearance of such remains but also their scientific value. Lynnerup (2015, fig. 1) dramatically illustrates the risks of allowing a body to dry out with the image of a twisted mandible, initially compressed by the overburden of peat and then warped as water has evaporated, so the condyles are bent double upon each other. It is, he warns, all too easy to attribute the damage wrought by such bone diagenesis to peri-mortem injuries. Yet for many of the antiquarian finds discussed in Chapter 1 there was no alternative than air-drying these remains, if they were to be curated for a collection.

This was the fate of late nineteenth-century discoveries such as Gallagh Man (found in 1821) as well as the Baronstown West body (found in 1953), both in the National Museum of Ireland (O'Floinn 1995). Bog bodies from the Netherlands (such as the Weerdinge couple, found in 1904, Exloërmond Man, found in 1914 and Emmer Efrscheifenveen Man, found in 1938); from Germany (Damendorf II, found in 1900, Jürdenerfeld Man, found in 1934 and Neu England Man, found in 1941); from Denmark (Elling Woman, found in 1938 and Huldremose Woman, found in 1879) and even from Poland (Dröbnitz Girl, found in 1939 but sadly destroyed in the war) were all 'air-dried'. As well as the warping and shrinkage deplored by Lynnerup, the technique also had other risks: museum basements and stores were not always the ideal atmosphere for such air-drying - Bunsoh 
Man and Husbäke I from Germany decayed so swiftly and pungently that all of their surviving remains were destroyed soon after (van der Sanden 1996: 79). The delicate balance between curating the remains and trying to gently dry them meant that bacterial growth and decay could not always be halted. Desiccation could also arise from the mere fact that the remains were subject to police or forensic interrogation, preventing remedial action (as we shall see with Worsley Man from Manchester, in the mid-1950s). Summarising the coarse conservation measures used on Rendswühren Man, Gill-Frerking (2014: 67) used digital radiographs to reveal the wire, steel rods and unidentifiable materials (which probably included modelling clay and cotton wool) to reconstitute and stabilise his fragile head.

Experiments in the conservation of waterlogged, peat-preserved human remains appear to have begun as part of a bolder move to 'intervene' in the decay cycle of an object, supported by changes in conservation philosophy, practice and the confidence of museum curators. This went hand in hand with the growth of archaeological science techniques from the mid-twentieth century onwards. Most of these interventions are thus post-war and accompany the growing cachet of bog bodies as an archaeological phenomenon, motivated by the desire to preserve the very properties and characteristics that made these remains remarkable (Tollefsen 2015). However, some pre-date the fame that Glob's monograph, Heaney's poetry and the archaeological documentary would bring. In 1871, Rendswühren Man was partially preserved through 'smoke tanning' or curing (Asingh and Lynnerup 2007: 308). This was based on the burning of wood to produces aldehydes that react with collagen and prevent further putrefaction (Brothwell 1986: 22) - a technique borrowed from millennia of culinary knowledge. The rather toxic substance of pentachlorophenol was used in the case of Dätgen Man, along with the use of copper and steel wire, small metal nails and a wooden rod, while the brain tissue of Windeby Girl was removed and replaced with putty (Gill-Frerking 2014: 68, 71). Meanwhile, in the 1940s, the bodies from Borremose were kept in zinc boxes, filled with formaldehyde: a forensic method used to preserve dead tissue that works on the principle of liquid substitution - fats and fluids being gradually replaced by formalin in an early kind of 'plastination' (Strehle cited in Asingh and Lynnerup 2007: 40). However, organic samples preserved in formaldehyde tend to become shapeless, inhibiting exhibition (as the conservator of Grauballe Man, LangeKornbak, later argued) (Strehle cited in Asingh and Lynnerup 2007: 40). These remains are still stored behind the scenes in the National Museum in Copenhagen. In the case of Kreepan Man, 'as the body became mouldy ... it was first treated with formalin, later with sublimate and later still paraffin wax was injected into it' (van der Sanden 1996: 89).

The first major conservation programme for bog bodies arose in the case of Tolland Man (Figure 3.1). When he was discovered in 1950, the Silkeborg Museum (then staffed voluntarily) took Glob's advice to send the remains to the National Museum in Copenhagen. With new premises about to be opened, the Silkeborg staff were eager to display these remains as soon as possible. Yet the senior 


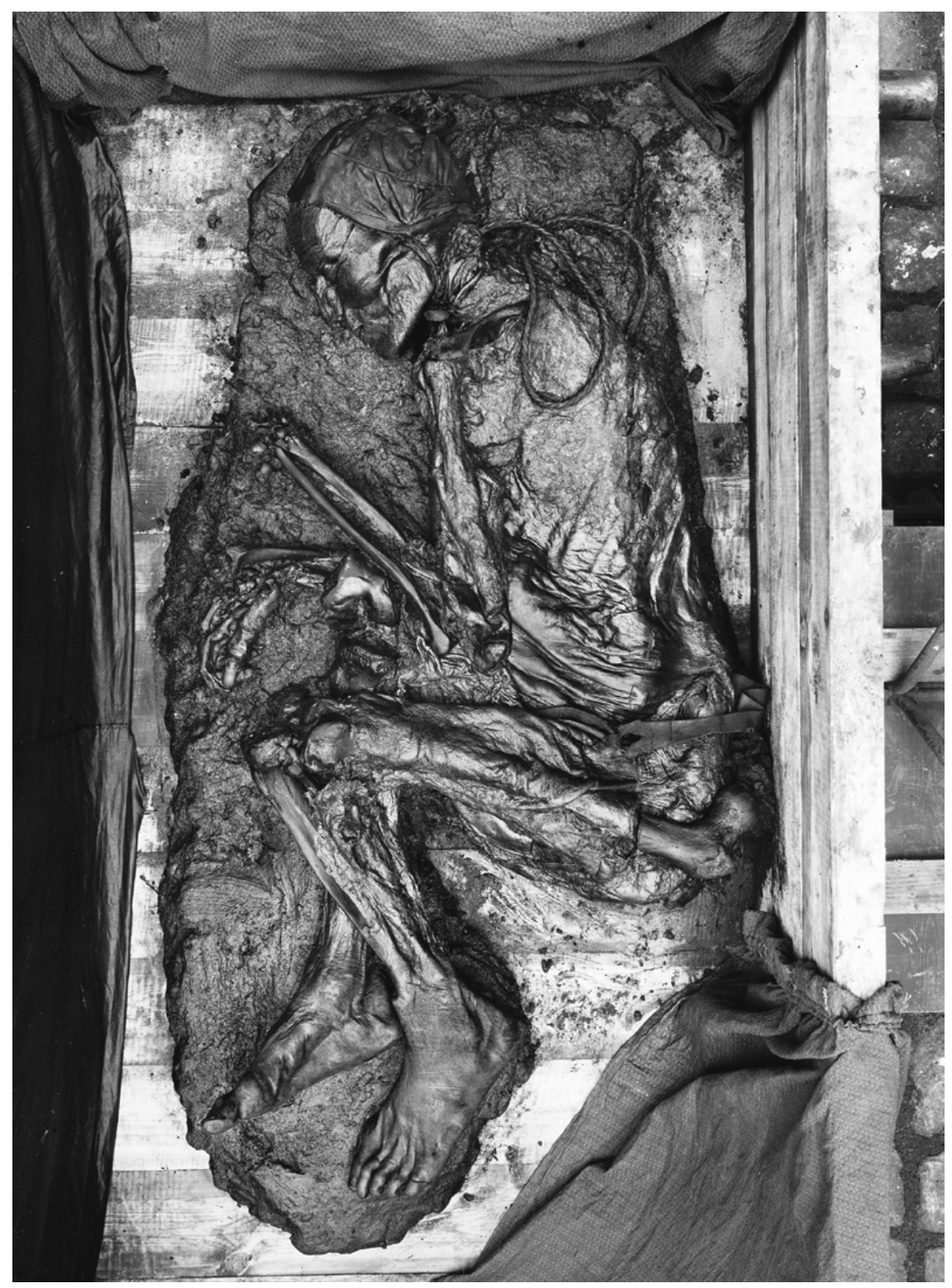

3.I Tolland Man, shortly after discovery. All rights reserved and permission to use the figure must be obtained from the copyright holder. 
curator of the National Museum and head of the Prehistoric Department, Therkal Mathiassen, did not share their enthusiasm, writing:

I see that Silkeborg Museum wishes to exhibit the find conserved in its entirety. However, I am not sure this would be a good idea. It is quite a macabre sight and ... it will be very difficult to conserve ... I believe we will have to suffice with simply retaining the head, which is exceptionally well preserved with facial expression etc., as well as the leather cap, the cord and the belt. (Cited in Fischer 2012: 31)

As Fischer (2012: 35) points out, images played a significant role here: the blackand-white newspaper images of the day portrayed Tollund Man lying on his righthand side (which was significantly more decayed and partially defleshed) and this exaggerated the disquieting effect of the remains. But the damage was done. In 1965 Glob himself described this decision in a restrained manner: 'Unfortunately it was only thought practicable to undertake conservation with the splendid head' (Glob [1969] 1971: 32). Knud Thorvildsen (Glob's conservator at Borremose, charged with the excavation and conservation of Tolland Man) wrote more bluntly: 'Following examination, Dr Vimtrup severed the corpse's head from the body' (cited in Fischer 2012: 50). The rest of the remains were retained but allowed to dry out with a few exceptions (Knudsen 1990), becoming desiccated, shrunken and deformed.

In the laboratory of the National Museum, the technique selected by conservators Thorvildsen and Christensen was apparently influenced by methods used to prepare specimens for microscopy, involving paraffin wax and dehydrating solutions (Strehle 2007: 4, Fischer 2012: 53). The head spent six months steeped in water, formalin and acetic acid, effectively creating an antibacterial fluid to replace the peaty bog water. The solution was then changed to 30 per cent alcohol, and then a further change to 99 per cent alcohol and a solvent, toluol, to avoid 'curdling' (Fischer 2012: 53). The final fluid contained paraffin with carnauba wax and a little beeswax, heated to dissolve and impregnate the head. One year later, the remains showed a shrinkage of approximately 12-14 per cent. Meanwhile, the leather cap, belt and cord were conserved using a lanolin mixture that has proved remarkably stable.

In addition, both feet were kept in a preservative fluid believed to be alcohol, but this substance has long since evaporated from one of the jars, damaging one foot considerably (Fischer 2012: 101). The well-preserved right thumb and toe were in better condition but only the former was returned to Silkeborg. In 1970, both right thumb and foot were conserved using polyethylene glycol (PEG) and freeze-dried, but the foot was later reported to show 'flaking' (Fischer 2012: 101). Desiccated remains of the torso were found on a shelf in the National Museum along with 'stripped' skeletal remains given to the Normal-Anatomical Institute (see Chapter 2). Preserved gut contents found in a jam jar at Moesgaard Museum were also discovered. This disassembling of the corpse might seem horrific to us, but as Fischer recalls, the ethics of displaying the dead at this time were very different: in Mathiassen's mind 'they should preferably be hidden away, and in the 
case of Tollund Man, ideally be forgotten altogether' (cited in Fischer 2012: 102). It was an era when senior curatorial staff of a national museum were seldom questioned, but Glob's own star was rising. By the time Grauballe Man was discovered in 1952, he reported that: 'it was unanimously agreed that the whole of this Iron Age man should be preserved for posterity ... [to ensure] that, at the end of the lengthy process of treatments envisaged, the dead man would still have the same bodily appearance and posture as when he had been uncovered in the bog' (cited in Glob [1969] 1971: 44). We can sense here the discourse of preservation as a way of ensuring an authentic encounter with the bog body; by now, having seen the ten thousand visitors queuing to see him on temporary display, Glob knew that they had an exhibit that people would flock to. Through this bold initiative, he had successfully transformed attitudes towards the display of the dead in Danish museums (Asingh and Lynnerup 2007: fig. 6) and after six months of analysis it was handed over to the skills of the conservator, Lange-Kornbak. During the research period, Lange-Kornbak repeatedly sprayed the body with distilled water, keeping it damp by 'watering' morning and evening, covering with wet sheets and oilcloth and using a phenol solution as a disinfectant to try and minimise the growth of white spores and insect infestation (Strehle 2007: 35). His diaries reveal that he then used a glycerin coating to create a complete and accurate plaster cast of the body and its death posture (analogous to the 'funerary masks' of the Victorian period), before immersing the corpse in an oak trough containing $875 \mathrm{~kg}$ of oak bark chips (Asingh and Lynnerup 2007: 29).

Moesgaard's conservator believed that the bog had begun 'an incipient tanning process which it was my task to complete' (cited in Strehle 2007: 42). Over the course of eighteen months, his bark solution was renewed three times (Glob [1969] 1971) before the 'tannic acid slime' was washed off (Asingh and Lynnerup 2007: 29). The chemical reaction induced by Lange-Kornbak's techniques had the advantage of creating a 'fuller and firmer leather' as Painter puts it (1995: 98): it shrank less upon drying but hardened. Grauballe Man was subsequently placed in a 10 per cent 'bath' of Turkish Oil (used as a softener (Strehle 2007: 44) not a detergent (cf. Omar et al. (1989)) and injected with a synthetic resin called 'Cellodal' to prevent further shrinkage. Minor cracks and splits as well as lighter patches in the skin were then 'finished' with a mixture of glycerine, lanolin and cod liver oil (Strehle 2007: 45), otherwise known as 'leather dressing' (Knudsen 1990; Asingh 2009: 61). The plaster cast acted as a model for Lange-Kornbak as he knew that the manipulation of the body during this period would have subtly altered Grauballe Man's disposition. He finally set about creating a 'good-looking' corpse by selective filling of the abdominal cavity with synthetic sponges and filling out of muscles with more Cellodal. These 'cosmetic' transformations might now be regarded as going beyond the contemporary conservation ethos of minimal or reversible intervention. Yet we must understand this treatment within the wider context of trying to shift Danish attitudes towards human remains, and Tollund Man's very selective curation (Strehle 2007: 46). The conservator was also dealing with the consequence of the fact that many people literally wanted a 'piece' of this 
body: the recent scanning and patient archival analysis undertaken by Asingh and Lynnerup (2007: 221) has revealed how four vertebrae were extracted from his back and sent to America for the study of blood groups. It was left to Lange-Kornbak to fill the hole (with sponge) and hide the post-mortem damage. Thus, there was not only a need but an ideal behind this work, great skill and some daring, much of which is not recorded in any notebook or archive; as Lange-Kornbak put it, 'like all good craftsmen, I will take my secrets with me to the grave' (cited in Asingh 2009: 64). There is a fitting irony that this master-conservator's fame rests in the preservation of another man's corpse.

Glob and his team aimed to produce an aesthetic encounter true to Grauballe Man's awe-inspiring yet intimidating appearance when lifted from the bog. The efforts they made continue to underpin how the Moesgaard Museum ensures he is 'exhibited with dignity and respect for the dead' (Asingh and Lynnerup 2007: 29). Overall shrinkage was recorded as c.9-10 per cent, an improvement on Tolland Man. Subsequent treatments were ministered by Lange-Kornbak, but by the 1980s, there was greater conservation resistance to the application of foreign substances to the body as well as a realisation that the heating and humidity arrangements within the gallery were taking a toll upon the corpse (although damaging ultraviolet (UV) light had been excluded). Today, after cleaning and application of lanolin in 2002, he lies in an oxygen-free case maintained at a slight positive pressure by nitrogen, in a relative humidity of $c .55$ per cent (Fredericksen and Glastrup 2007: 63; Strehle 2007: 50).

By the 1980s, the approach taken to the conservation of Lindow Man was influenced by advances in treating waterlogged remains from a series of wetland sites in the UK discovered in the 1970s-1980s, particularly the use of impregnation with (polyethylene glycol (PEG) and freeze-drying of wood and other organics (Daniels 1996; Joy 2009: 36). Freeze-drying had been attempted with Tolland Man's foot but this had never before been attempted for a complete body (Joy 2014c: 15). Ian Stead (curator of the Iron Age at the British Museum) thus commissioned a series of experiments from his conservation team (Omar and McCord 1986: 19). The first stage was a chemically induced pre-drying treatment using PEG to minimise shrinkage. Samples of pigskin were impregnated with a 15 per cent solution of PEG 4000 in distilled water for ten weeks. They were then removed, wrapped in cling film and frozen to $-26^{\circ} \mathrm{C}$ for three days, then freeze-dried for four weeks, before re-acclimatising to a relative humidity of 55 per cent at room temperature. Results showed that there was shrinkage of less than 5 per cent, which was a marvellous improvement on the prior Danish methods, but this was at the expense of appearance: there was a lightening of colour and greater rigidity of body, though the treatment did enhance the clarity of skin (Omar and McCord 1986: 20).

The conservation experiments gave the researchers time to conduct their forensic examination and sampling programme, but pressure on both teams (as well as the risk of elevated temperature) was intensified by the QED camera team filming for a documentary released by the BBC in 1985 (Omar and McCord 1986: 17). Following the excavation of the remains in the lab to remove peat, a 
mount was made to support the handling and turning over of the body using cling film as a fine intermediary layer, covered by strips of fibreglass casting tape that set hard, further strengthened by a polyester resin and further strips of fibreglass (Omar and McCord 1986: 17). After careful cleaning, Lindow Man was then placed on a Perspex slab and treated with the above 15 per cent PEG 4000 solution for twenty-nine days at $-28^{\circ} \mathrm{C}$ (Omar and McCord 1986: 20). The time period seems to have been determined by repeated weighing, ceasing sublimation when 'negligible weight loss occurred' (Omar et al. 1989: 107). The body was then allowed to slowly acclimatise to a relative humidity of 55 per cent at room temperature (Omar and McCord 1986: 20). The success of the freeze-drying method has made it the accepted conservation technique for new bog bodies (principally employed in Ireland, see Mulhall 2010).

However, there were problems. Fine cracks and differential colour streaking prompted further remedial surface treatment in June 1986, with three applications of 10 per cent PEG 4000 in distilled water followed by one 50 per cent PEG 4000 application to the lightest and driest areas of skin (Bradley et al. 2008: 274). Despite the technique's minimisation of shrinkage, the 'lightening' effect of the treatment was compounded by Lindow Man's variable display, which by 1988 (after a brief tour to Manchester) was relocated in the Central Saloon (galleries 36 and 37) making a captivating display at the top of the main flight of stairs (Bradley et al. 2008: 274). The conservation parameters for the case at this time were a relative humidity of 55 per cent $+/-5$ per cent at ambient room temperature (which slightly fluctuated according to the season) and light levels permitted to 100 lux, although UV light was excluded. While he was a well-visited ambassador to tempt visitors further into the prehistoric galleries of the British Museum, he lay under the natural spill from skylights and fluorescent lighting illuminating the nearby Hinton St Mary mosaic, exposing him to up to 1200 lux (Bradley 2005: 161-2; Bradley et al. 2008: 274). By 1990 a canopy was erected to reduce light damage and covers were placed over the body out of hours (Bradley et al. 2008: 275). But by 1997, these effects led Ian Stead to move the remains into the more sheltered, dimmer light of the main Iron Age gallery in room 50 (Joy 2014c: 17). His current steel and glass case ensure his remains have been stabilised to within $1^{\circ} \mathrm{C}$ of the $20^{\circ} \mathrm{C}$ limit with a relative humidity to within 2 per cent of the 55 per cent threshold, and to light levels of within 30-50 lux (Joy 2009: 37). By turning the case inwards towards the walls, the risk of UV damage has also been minimised, arguably also giving these remains their own space and privacy (Giles 2009; Joy 2014c; see Figure 3.2). The re-evaluation of his remains in 2005 monitored the light damage, evaluated an apparent white bloom on the skin (identified as residue from the polyester bonded fabric used to support the body during PEG treatment) and confirmed the success of the final surface treatment with PEG, in closing cracks and continuing to act as a humectant (Bradley et al. 2008: 278). Some oxidation of the PEG had occurred, but (other than the effect of light damage) the body was considered to be in stable and good condition after twenty years of display (Bradley et al. 2008: 281). 


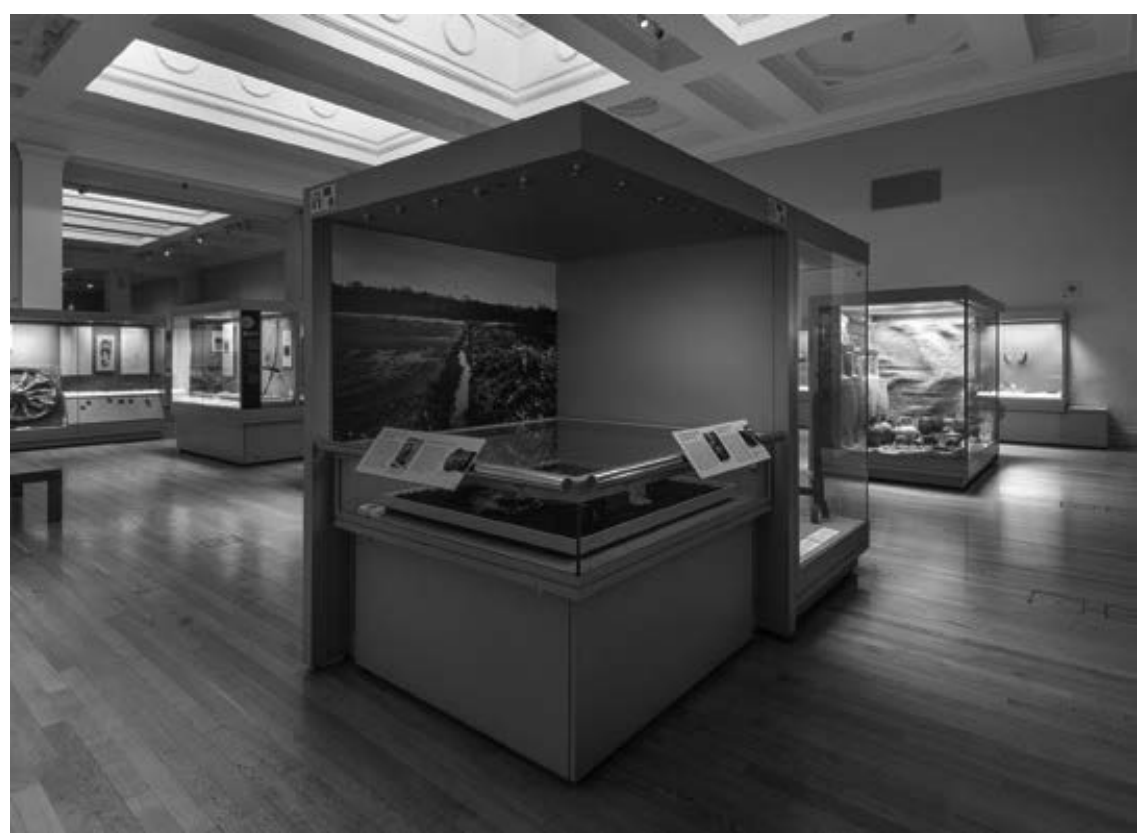

3.2 Lindow Man on display (C The Trustees of the British Museum).

The lessons learned from Lindow Man have certainly informed the conservation of the latest bog bodies to emerge from the peat - principally those of Meeneybradden Woman (Omar et al. 1989), Tumbeagh (Bermingham and Delaney 2004), Old Croghan Man and Clonycavan Man (Mulhall and Briggs 2007; Kelly 2013), all from Ireland. These remains were preserved using the same 15 per cent PEG 4000 solution employed with Lindow Man for four weeks, followed by six weeks of freeze-drying (Mulhall 2010: 36). Similar to Lindow Man, a final surface dressing of 5 per cent PEG in ethanol was applied to the bog bodies (Mulhall 2010: 36). Detailed publication of the Irish case studies is still eagerly awaited, as is a longitudinal evaluation of their stability, appearance and shrinkage factors, but the early results appear impressive. Meanwhile, other remarkable discoveries from Irish bogs have prompted new innovations in the treatment of fragile organic skin products. PEG treatment and freeze-drying was not considered effective for the delicate surfaces of ink on vellum posed by the Fadden More Psalter (Gillis 2014). Challenged to develop another method of gently drying and separating its pages, vacuum-drying with ethanol replacement has proved effective and offers a new technique yet to be tested on human remains (Reed pers. comm.).

In reviewing the different methods used to conserve bog bodies, we have seen the use of late-nineteenth-century culinary and storage knowledge shift to 
a mid-twentieth-century era of curatorial skill and improvisation with preservative fluids and substances. Finally, the rigours of scientific testing, experimentation and monitoring that accompanied the rise of conservation science in the later twentieth and twenty-first century were brought to bear on this phenomenon. Yet it is obvious that it is not just the 'recipes' and methods deployed on these remains that determine their fate: the circumstances of their exposure, delays in conservation, the contemporary ideology of what should or should not be seen, along with the history of their display, lighting and humidity, also shape their final appearance. As a result, the challenges faced by archaeologists not only in the field and the laboratory but the gallery itself, should be brought within the compass of these conservation histories. We need more longitudinal studies of bog bodies to inform future care, for even the 'best practice' standards set out above will, in time, fail. The illusion that we too now possess the skill to stop time is just that - we have delayed it, deferred it, but at some point must ultimately surrender these bodies to decay. Why even try? What prompts us to finish this work of the bog, as LangeKornbak put it (cited in Asingh 2009: 54)? It is to the philosophical ideas that underpin conservation and how this relates to the experience of being with the dead that this chapter finally now turns.

\section{Conserving the dead: a form of deceit or a kind of care?}

There is an ontological dilemma at the heart of bog body studies. Put simply, their value lies in the fact that they are human remains that appear to stand outside of time. Yet as the above section has revealed, this 'preservation of naturalness is done artificially' (Sanders 2009: 178). They only continue to survive by our hand. Is the conservation through which they continue to stall time a form of deceit or a kind of care?

No body brings this into sharper focus than the remains of Tolland Man. For many years, his head was displayed in its 'decapitated' state: the result of a modern conservation decision rather than any Iron Age brutality. Yet under the visionary curatorship of Christian Fischer it was decided that the viewing public might like to see what he looked like when he was found in 1950. In one sense this was the physical realisation of Glob's volume, in which Sanders (2009: 19) argues that he 'sutures the dissected body through poetic and photographic glossing, achieving 'almost a re-embalming. The idea of rehydrating or trying to restore the different body parts collated from the National Museum in Copenhagen was quickly dismissed, due to the inevitable damage this post-mortem 'resurrection' would have upon the original remains (Fischer 2012: 106). Instead, the remaining body parts coupled with the exquisite black-and-white photographs were used as models for a three-dimensional cast made by the Natural History Museum in Denmark under the direction of conservator Lars Bo Nielsen (Fischer 2012: 107). As Fischer (2012: 107) puts it, the final reconstruction was 'to be carefully evaluated aesthetically and ethically'. There was a very real possibility that the replica 
would be rejected. The first people to view the simulated whole were the Højgaard family who had discovered the remains. In a telling phrase, Fischer (2012: 106) recalls, 'They were in no doubt - it was him they found'.

This was not literally true of course, yet what does it tell us? The cultural heritage author Cornelius Holtorf (2007: 118) has argued that 'visitors ... experience authenticity and aura in front of originals to exactly the same degree as they do in front of very good reproductions or copies, as long as they do not know'. Yet this deception is, for others, unethical, touching deeply upon the philosophical tenets of William Morris, to only carry out 'fair repair' that is honest about its interventions (see Pye 2001b). In Silkeborg Museum, a small label warns visitors about the complex history of what they are seeing, but it can be quite easily overlooked and the eventual encounter does not foreground this fact, generating instead an aesthetically moving, one-to-one, eye-level encounter with the remains. Its effectiveness is clear - while the body that inspired Heaney to write 'Tollund Man' was of course the photograph taken in 1950, the one he finally saw in person would have been this hybrid simulacrum. Holtorf (2017: 497) is right in thinking that 'clever copies, reconstructions and imaginative inventions can possess age-value too' Yet does the post-cranial simulacrum of Tolland Man matter? The issue hinges on our obsession with authenticity. We have already encountered the 'uncanny' power of the bog body, but as Sanders (2009: 50, original emphasis) argues: '[Their] uncanniness rests on our experience of authenticity: they are the real thing! On the other hand, their uncanniness rests on the possibility that they are not real, that they are ghostly simulacra harboring a double uncanniness of being both "un-heimlich" (un-homely) and "un-zeitlich" (un-timely) - a unique "material reality". In the case of Tolland Man, this uncanny power is redoubled by the fact that the very corpse is both real and unreal. This conundrum was brought into even sharper focus when in 2016 the current curator of Silkeborg, Ole Nielsen, received a phone call from the descendants of the conservator Brorson Christiensen, who had worked on Tolland Man. The 'missing' right big toe had been found wrapped in tissue paper in their mother's effects, prompting them to remember that their father used to bring this body part out from his housecoat pocket at the end of the day or to show guests (Museum Silkeborg 2019). Whether it was to shock or appal, we can only guess, but the toe was in good company: old coins and fragments of conserved wood from the Roskilde Viking ships were also among this 'pocket treasure'. I like to think he carried with him fragments from the past that could hold others spellbound, knowing it was his skill that helped produce this moment of contact with the past. For Nielsen, however, it created a new dilemma: should the toe now go on display in its own right, drawing further attention to the simulacrum, or should it be kept behind the scenes (Nielsen pers. comm.)?

The problem relates to the undue emphasis that the West places upon the material authenticity of the past, as Jones and Yarrow note (2013). This ideal is based in the nineteenth-century debates over the value of 'original fabric': whether to permit the heavy restoration of ruins and relics to their past glory (seen in the work of Eugène Viollet-le-Duc) or to effectively manage the decay that the 
Romanticists argued actually gave sites and finds their aura - the 'golden stain of time' (Ruskin 1849: 177; see also Pye 2001b). We now recognise that authenticity can be found also in intangible concepts; in Glasgow cathedral, this includes the 'prayerfulness' that continues to shape a religious building or the skills that its stonemasons believe they are both learning from their forebears and continuing to practice in their own carvings (see Jones and Yarrow 2013). How then can we ensure that people have the kind of 'magical communion' Jones (2010: 142) evokes or the 'near religious or spiritual experiences' that Fredengren (2016: 484) argues can be common with waterlogged materials without any 'sleight of hand' about what people are seeing? The answer could be found in Jones's notion that the 'authentic' value of the past lies not just in the obdurate matter of a thing but in our experience of the relations between objects, people and places that such things embody:

\begin{abstract}
The materiality of objects is crucial here, as is some form of physical contact or intimate experience of them. This is not to do with their origins, material, form, or provenance, in a materialist sense, but rather because the materiality of objects embodies the past experiences and relationships that they have been part of and facilitates some kind of ineffable contact with those experiences and relationships. This leads to a powerful magical or enchanting quality, in that these past experiences and relationships appear to be carried along by the object in an almost contagious manner. (Jones 2010: 137)
\end{abstract}

If we include not just the touching or violent relations that have wrapped or wounded these people in the past, but the hands of those who lifted them from the peat and the curators and conservators who have further worked upon them, we do not diminish but enrich their biography (Narkiss 2009: 239). We become mindful of Benjamin's (1969: 221) original definition of aura as encompassing all the histories these remains have experienced: Ruskin's (1849: 15) 'passing waves of humanity' that collectively accrete within these bodies. The 'afterlife' of these remains, once they enter a museum is not static, an end point (Muños-Viñas 2005). We should not narratively 'cut off' time again in the moment of exposure from the peat; the story of those discoveries and their conservation histories become accounts of care given to the dead. Part art, part science, curators and conservators are, in their own way, members of the profession of 'death workers' in which archaeology should rightly claim a place (Williams and Giles 2016).

Human remains thus have a unique role in this conservation philosophy debate. As a category of archaeology, they have an 'evidential power', a forensic capital, as Crossland (2009) rightly warns us, which is created in part through the performative practice of exhumation, analysis and curation. Conservation is thus part of their afterlives: an influential way in which new skeins of social relations are made with the living, which as we have seen, can determine what is kept or thrown away, reburied or displayed (Narkiss 2009). Even if we accept this resolution, we face another problem. How do we draw attention to the traces of agevalue that Riegl exhorted us to look for? Holtorf (2013: 427) argues that 'pastness' as a quality is experienced not through intellectual knowledge or scientific analysis but our sensory engagement with things: 'patina, cracks and missing bits ... evoke 
the notion of a fragile heritage from another time ... that seem to beg for the attention of a conservator' (Holtorf 2013: 432). Yet the mummification of the bog slows and halts the very processes that give most finds their auratic power. Whether it is with diligent dabs of 'leather dressing' or PEG washes, bog body conservators have also sought to hide the traces of time that Holtorf looks for in a vessel, garment or sculpture to convey its age-value. If 'decay informs the experience of authenticity as a tangible mark of age and "the real"' (Douglas-Jones et al. 2016: 823), then we are indeed in difficult terrain. This principle will not work for bog bodies: we would be accused of failures of care, precisely because this was once, and arguably still is, human.

Instead, I would suggest that we can strategically foreground intimate connections with past humanity: those delicate whorls on Grauballe Man's feet, the neat hair plait of Elling Woman, the scrap of fox fur wrapped around Lindow Man's arm. Such moving insights into the personal attributes or possessions of the dead help evoke the 'ineffable contact' and 'numinous or magical quality' that Jones (2010: 193) argues encourages people to reach out, to try to touch 'as if this would achieve some magical communion with the past' (remember Valerie Hall and her team, reaching out to the hand of Old Croghan Man). We can also use this strategy to guard against Sanders's (2009: 30) concern that conservation risks 'aestheticising' bog bodies by substituting 'trauma with nostalgia' (Sanders 2009: 34). Death may be a difficult theme to illustrate archaeologically (Giles 2016b: 418), 'resisting representation' (Scarry 1995). Yet as Scarry (1995: 22) advocates, we can connect with someone's pain by visualising the wound, or with their labour by seeing the material traces of their work in the world: the fracture or cut, violently enacted upon the body alongside their life work, engrained in hands, feet, teeth.

In Moesgaard Museum, a whole room is dedicated to the conservation history of Grauballe Man, detailing the ideology as well as the methods behind his preservation and introducing the visitor to the people who discovered and cared for him. That web of relationships, and the science and knowledge behind it, is fulsomely exposed for the viewer, in a way that only deepens the marvel of his remains. Grauballe Man himself lies next door in a peat-coloured room. His glass case is surrounded by a bench that brings you face to face with the warped ebony of his skin and the 'elderberry' gash of his slashed throat. In the dim light of this personal communion, his humanity appeals to us, just as his fate appals us. Heaney would, I am sure, approve.

\section{Conclusion}

The chapter has discussed the uncanny humanity of the bog body and how this has affected their reception. It has argued that this can create both unsettling and moving encounters, given them a unique haunting power. In common with other authors, it has suggested that this iconic aura arises from the way in which these remains defy time. Yet it has revealed that this appearance is a deceit, maintained 
through methods of archaeological conservation. This has created a philosophical quandary for curators about how much of this process they should show or reveal. Having reviewed both the science of bog preservation and the methods employed in curating bog bodies, the chapter argues that the two processes entwine in a form of artful science that together produce Heaney's 'riddling power'. Instead of criticising such work as an intervention that undermines the authenticity of a bog body, conservation here has been embraced as a kind of care. It has argued that this deepens the experiences we have with these remains: magnifying our encounter, enriching the connections we make with them and widening the relations through which the afterlife of these individuals is assured. Having dwelt for a while with the remains themselves, I want now to turn - as any archaeological investigation would - to the context of this discovery, to ask: why were they buried here? 